\title{
Interleukin-15 augments oxidative metabolism and fungicidal activity of human monocytes against Paracoccidioides brasiliensis
}

\author{
Camila Ferreira Bannwart/ ${ }^{+}$, Rosana A Rodrigues Martins, Érika Nakaira-Takahashi, \\ Luciane A Dias-Melício, Ângela MV Campos Soares, Maria Terezinha S Peraçoli
}

Departamento de Microbiologia e Imunologia, Instituto de Biociências, Universidade Estadual Paulista, Botucatu, SP, Brasil

\begin{abstract}
Interleukin (IL)-15 is a pleiotropic cytokine that regulates the proliferation and survival of many cell types. IL-15 is produced by monocytes and macrophages against infectious agents and plays a pivotal role in innate and adaptive immune responses. This study analyzed the effect of IL-15 on fungicidal activity, oxidative metabolism and cytokine production by human monocytes challenged in vitro with Paracoccidioides brasiliensis (Pb18), the agent of paracoccidioidomycosis. Peripheral blood monocytes were pre-incubated with IL-15 and then challenged with Pb18. Fungicidal activity was assessed by viable fungi recovery from cultures after plating on brain-heart infusion-agar. Superoxide anion $\left(\mathrm{O}_{2}^{-}\right)$, hydrogen peroxide $\left(\mathrm{H}_{2} \mathrm{O}_{2}\right)$, tumour necrosis factor-alpha (TNF- $\alpha$ ), IL-6, IL-15 and IL-10 production by monocytes were also determined. IL-15 enhanced fungicidal activity against Pb18 in a dose-dependent pattern. This effect was abrogated by addition of anti-IL-15 monoclonal antibody. A significant stimulatory effect of IL-15 on $\mathrm{O}_{2}^{-}$and $\mathrm{H}_{2} \mathrm{O}_{2}$ release suggests that fungicidal activity was dependent on the activation of oxidative metabolism. Pretreatment of monocytes with IL-15 induced significantly higher levels of TNF- $\alpha, I L-10$ and IL-15 production by cells challenged with the fungus. These results suggest a modulatory effect of IL-15 on pro and anti-inflammatory cytokine production, oxidative metabolism and fungicidal activity of monocytes during Pb18 infection.
\end{abstract}

Key words: IL-15 - Paracoccidioides brasiliensis - monocytes - hydrogen peroxide - fungicidal activity - cytokines

Interleukin (IL)-15 is a cytokine originally discovered in 1994 as having a T cell stimulatory activity present in the culture supernatant of a simian kidney epithelial cell line that requires $\beta$ and $\gamma$ chains of IL-2 receptor for binding and signaling (Grabstein et al. 1994). A special feature of IL-15 is that it shares important functional attributes with IL-2, including enhanced proliferation, survival and differentiation of many distinct cell types as natural killer cells (NK), $\alpha \beta$ and $\gamma \delta$ T cells, B cells, macrophages and neutrophils (Carson et al. 1994, Grabstein et al. 1994, Nishimura et al. 1996, Yoshikai \& Nishimura 2000, D'Agostino et al. 2004). Sharing of receptor subunits between IL-2R/IL-15R chains can explain part of the existing functional similarities. IL-15 is a cytokine of innate immunity that modulates selected adaptive immune responses (Van Belle \& Grooten 2005); IL-15 mRNA is constitutively expressed in a large variety of cell types and plays a role in a broad spectrum of bio-regulatory purposes (Grabstein et al. 1994, Musso et al. 1999). Few reports describe the response of monocytes and macrophages to stimulation with IL-15 through an increase in phagocytosis and microbial clearance and increased production of IL-8, IL-12 and monocyte chemotactic protein-1, which in turn attract monocytes and neu-

Financial support: FAPESP (03/13743-0, 05/54283-7)

+ Corresponding author: cfbannwart@ibb.unesp.br

Received 9 April 2010

Accepted 15 June 2010 trophils, leading to inflammatory cell accumulation (Vázquez et al. 1998, D’Agostino et al. 2004). The modulatory effect of IL-15 on the host response to infectious agents has also been reported, suggesting that this cytokine may have a potent protective role against a variety of microorganisms (Nishimura et al. 1996, Winn et al. 2003, Forcina et al. 2004). The information provided by the literature therefore indicates that IL-15 is especially produced by monocytes and macrophages in response to infectious agents and that it constitutes an important pro-inflammatory cytokine (Carson et al. 1994).

Infection with Paracoccidioides brasiliensis (Pb18), a dimorphic fungus, can result in paracoccidioidomycosis (PCM), which is a systemic mycosis endemic and prevalent in Latin America that infects individuals via the respiratory route. Inhaled fungal spores reach alveolar spaces, where they are ingested by resident macrophages, and depending on the subsequent immune mechanism, the disease can develop as an acute systemic or as a chronic localized mycosis (Franco 1987, Franco et al. 1989, Brummer 1994). The aetiological agent is considered an intracellular pathogen, which makes studies of its interaction with phagocytic cells essential to understand the host-parasite relationship. However, the modulation of the mononuclear phagocyte during Pb18 interactions has not been fully elucidated. Previous studies showed the lack of fungicidal activity by human monocytes against the highly virulent $\mathrm{Pb} 18$, even after IFN- $\gamma$ activation. These results were associated with the capacity of the fungus to induce prostaglandins, as reflected in the significant fungicidal activity detected after treatment of monocytes with indomethacin, a cyclooxygenase inhibitor (Soares et al. 2001, Bordon et al. 2007). Monocytes/ 
macrophages play an important role in the immune response in certain mycoses and they are involved in the innate mechanisms against fungal infections (Smith et al. 1990, Louie et al. 1994). Several studies have reported in vitro stimulation of human monocytes/macrophages with different fungi or their cell wall components such as Coccidioides immitis (Dooley et al. 1994), Cryptococcus neoformans (Vecchiarelli et al. 1995) and P. brasiliensis (Anjos et al. 2002, Peraçoli et al. 2003, Kurokawa et al. 2007), suggesting that these cells are the main source of tumor necrosis factor-alpha (TNF- $\alpha$ ), IL-1, IL-6 and IL10 production and that they play a pivotal role in the immune response against these fungi.

The purpose of the present study was to evaluate whether human monocytes stimulated with IL-15 have the capacity to enhance fungicidal activity against $\mathrm{Pb} 18$ and this effect is related to the release of superoxide anion $\left(\mathrm{O}_{2}^{-}\right)$and hydrogen peroxide $\left(\mathrm{H}_{2} \mathrm{O}_{2}\right)$, which are the metabolites involved in Pb18 killing by human monocytes. In addition, the effect of IL-15 on the levels of pro and anti-inflammatory cytokines produced by monocytes such as TNF- $\alpha$, IL-6, IL-15 and IL-10 was investigated.

\section{SUBJECTS, MATERIALS AND METHODS}

Subjects - Twenty-five healthy blood donors from the University Hospital of Botucatu Medical School, São Paulo State University, Brazil, who tested negative for paracoccidioidin (age range 20-50 years), were included in this study. The Research Ethical Committee of Botucatu Medical School approved the study and an informed consent was obtained from all the blood donors.

Fungus - The highly virulent $\mathrm{Pb} 18$ was used in this study. $\mathrm{Pb} 18$ yeast cells were maintained by weekly subculture in the yeast form at $35^{\circ} \mathrm{C}$ on $2 \%$ glucose, $1 \%$ peptone, $0.5 \%$ yeast extract and $2 \%$ agar medium (GPY medium, all from Gibco Laboratories, Grand Island, NY, USA) and used on the 6th day of culture. Yeast viability was determined by phase contrast microscopy and bright yeast cells were counted as viable, whereas dark cells were considered not viable (Soares et al. 2001). Fungal suspensions containing more than $95 \%$ viable cells were used in the experiments.

Monocytes culture - Peripheral blood mononuclear cells (PBMC) were isolated from heparinized venous blood samples by density gradient centrifugation with Histopaque $^{\circledR}$-1077 (Sigma-Aldrich, Inc, St. Louis, MO, USA). The PBMC suspension was stained with neutral red $(0.02 \%)$, which is incorporated by monocytes and allows their identification and counting. Monocyte preparations routinely contained $>90 \%$ monocytes as determined by morphological examination and staining for nonspecific esterase ( $\mathrm{Li}$ et al. 1973). After incubation for $2 \mathrm{~h}$ at $37^{\circ} \mathrm{C}$ in $5 \% \mathrm{CO}_{2}$, non-adherent cells were removed from the plates and each well was rinsed twice with Roswell Park Memorial Institute (RPMI)-1640. The adherent cells, which were monocytes, were suspended to $2 \times 10^{6}$ or $1 \times 10^{6}$ monocytes $/ \mathrm{mL}$ in a complete tissue culture medium consisting of RPMI-1640 (Sigma-Aldrich) supplemented with $2 \mathrm{mM}$ of L-glutamine (Sigma-Aldrich), $40 \mu \mathrm{g} / \mathrm{mL}$ of gentamicin (Gibco Laboratories) and 10\% heat-inactivated autologous human serum. Monocyte suspensions were dispensed in 96-well flat-bottom plates (Nunc, Life Tech Inc, MD, USA) and treated with IL-15 at different concentrations (50, 25 and $12.5 \mathrm{ng} / \mathrm{mL}$ ) (R\&D Systems, Minneapolis, MN, USA) during $24 \mathrm{~h}$ for fungicidal activity, $\mathrm{O}_{2}^{-}$and $\mathrm{H}_{2} \mathrm{O}_{2}$ assays. Addition of $1 \mu \mathrm{g} / \mathrm{mL}$ anti-IL-15 monoclonal antibody (MoAb) (R\&D Systems) was performed in some experiments for IL-15 neutralization, according to the manufacturer's instructions. Cell suspensions containing $1 \times 10^{6}$ monocytes/ $\mathrm{mL}$ were dispensed in 24-well flat-bottom plates (Nunc) for culture supernatant cytokine measurement assays.

Fungicidal activity assay - Following IL-15 and antiIL-15 IgG1 MoAb treatments, monocyte cultures were washed with RPMI medium and challenged for $4 \mathrm{~h}$ in $5 \%$ $\mathrm{CO}_{2}$ at $37^{\circ} \mathrm{C}$ with $100 \mu \mathrm{L}$ of a $\mathrm{Pb} 18$ suspension containing $4 \times 10^{4}$ fungal cells $/ \mathrm{mL}$ (in a ratio of 50 monocytes per 1 fungal cell) prepared in complete medium plus $10 \%$ fresh human $\mathrm{AB}$ serum, as the source of complement for yeast opsonization. Co-cultures of monocytes and fungus were harvested by aspiration with sterile distilled cold water to lyse the monocytes. Each well resulted in a final volume of $2.0 \mathrm{~mL}$ and $100 \mu \mathrm{L}$ of this preparation was plated on supplemented brain-heart infusion-agar medium (Difco Laboratories, Detroit, MI, USA) plates containing $0.5 \%$ of gentamicin, $4 \%$ horse normal serum and $5 \%$. brasiliensis strain 192 culture filtrate $(\mathrm{v} / \mathrm{v})$, which constituted the source of growth-promoting factor (Singer-Vermes et al. 1992). Experiments using neutralizing anti-IL-15 MoAb were performed to analyze the role of IL-15 on fungicidal activity. The inoculum used for the challenge was plated under the conditions described above. The plates containing the material obtained from the monocyte-fungus co-cultures were considered the experimental plates and those plated with the fungus inoculum alone and counted at time zero, were used as controls. The inoculated plates were incubated in triplicates for each culture at $37^{\circ} \mathrm{C}$ in sealed plastic bags to prevent drying. After 10 days, the number of colony forming units (CFU) per plate was counted. Fungicidal activity percentage was determined by the following formula: $\%$ fungicidal activity $=[1-$ (mean CFU recovered on experimental plates/mean CFU recovered on control plates)] x 100.

Respiratory burst assay - $\mathrm{O}_{2}^{-}$production was measured with an assay for superoxide dismutase-inhibitable cytochrome c reduction and $\mathrm{H}_{2} \mathrm{O}_{2}$ release was measured by the horseradish peroxidase-phenol red oxidation method described by Russo et al. (1989). Briefly, after monocyte activation for $24 \mathrm{~h}$ in $5 \% \mathrm{CO}_{2}$ at $37^{\circ} \mathrm{C}$ with IL15 at different concentrations (50,25 and $12.5 \mathrm{ng} / \mathrm{mL}$ ), the monocyte cultures were washed with RPMI medium and challenged with $100 \mu \mathrm{L}$ of a $\mathrm{Pb} 18$ suspension prepared with $4 \times 10^{4}$ yeast $/ \mathrm{mL}$ plus $10 \%$ fresh human $\mathrm{AB}$ serum diluted in cytochrome $\mathrm{c}$ partially acetylated from horse heart (Sigma-Aldrich) for $\mathrm{O}_{2}{ }^{-}$assay. For $\mathrm{H}_{2} \mathrm{O}_{2}$ assay, $100 \mu \mathrm{L}$ of $\mathrm{Pb} 18$ suspension were prepared with $4 \mathrm{x}$ $10^{4}$ yeasts $/ \mathrm{mL}$ in phenol red buffer containing $50 \mu \mathrm{g} / \mathrm{mL}$ of horseradish peroxidase type II (Sigma-Aldrich). The $\mathrm{O}_{2}{ }_{2}^{-}$and $\mathrm{H}_{2} \mathrm{O}_{2}$ reactions were incubated for $60 \mathrm{~min}$ in $5 \%$ $\mathrm{CO}_{2}$ at $37^{2} \mathrm{C}$ and the $\mathrm{H}_{2} \mathrm{O}_{2}$ assay was stopped by addition 
of $10 \mu \mathrm{L}$ of $1 \mathrm{~N} \mathrm{NaOH}$. The absorbance at $550 \mathrm{~nm}$ and $620 \mathrm{~nm}$ for the $\mathrm{O}_{2}{ }^{-}$and $\mathrm{H}_{2} \mathrm{O}_{2}$ assays, respectively, were determined spectrophotometrically for each sample supernatant with a micro-enzyme-linked immunosorbent assay (ELISA) reader (MD 5000; Dynatech Laboratories Inc, Chantilly, VA, USA). The $\mathrm{O}_{2}^{-}$was calculated by using the extinction coefficient for reduced cytochrome $\mathrm{c}$ and transformed into nanomoles $\mathrm{O}_{2}^{-12} \times 10^{5}$ cells. An $\mathrm{H}_{2} \mathrm{O}_{2}$ standard curve was produced with serial dilutions from 0.5-8 nanomoles to convert absorbance into nanomoles $\mathrm{H}_{2} \mathrm{O}_{2} / 2 \times 10^{5}$ cells.

Cytokine measurement - The monocytes were cultured in the presence of $10 \mu \mathrm{g} / \mathrm{mL}$ Escherichia coli O55B5 lypopolisaccharide (LPS) (Sigma-Aldrich), which was used as the positive control culture and $50 \mathrm{ng} / \mathrm{mL}$ IL-15 (R\&D Systems) during $24 \mathrm{~h}$. Then, monocyte cultures were washed with RPMI medium and challenged with $\mathrm{Pb} 18$ for $18 \mathrm{~h}$. Cytokine concentrations were determined in monocyte culture supernatants by ELISA, using Quantikine ELISA kits (R\&D Systems) for TNF- $\alpha$, IL-6, IL-15 and IL-10 according to the manufacturer's instructions.

Statistical analysis - The results were compared by analysis of variance (ANOVA) followed by Tukey's test using INSTAT 3.05 software (GraphPad San Diego, CA, USA). The level of significance was set at $\mathrm{p}<0.05$.

\section{RESULTS}

IL-15 increases fungicidal activity - The fungicidal activity of human monocytes against $\mathrm{Pb} 18$ was significantly enhanced when the cells were treated with IL-15 for $24 \mathrm{~h}$. Monocytes activated with IL-15 concentrations of 50, 25 and $12.5 \mathrm{ng} / \mathrm{mL}$ killed $47.3,36.3$ and $23.2 \%$ of growing $\mathrm{Pb} 18(\mathrm{p}<0.05)$, respectively, showing a dose-dependent pattern. Experiments using a neutralizing antibody against IL-15 showed that the fungicidal activity was inhibited by treatment with the anti-IL-15 IgG1 MoAb (Fig. 1).

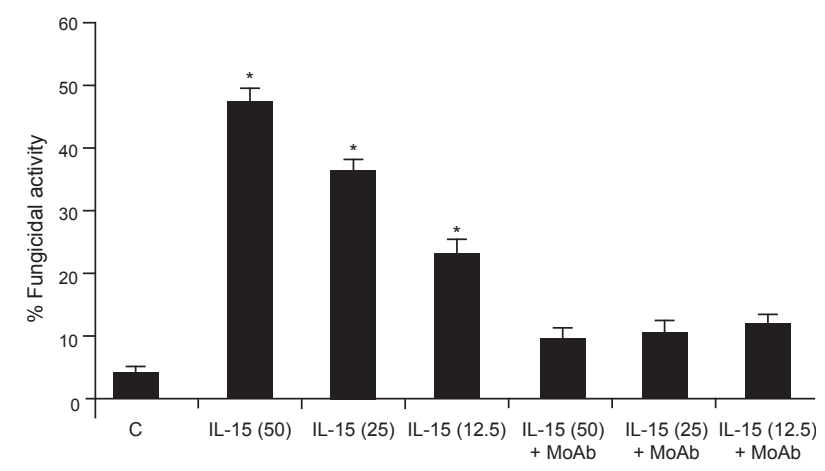

Fig. 1: interleukin (IL)-15 increased fungicidal activity of human monocytes against Paracoccidioides brasiliensis ( $\mathrm{Pb18}$ ). Monocytes were treated with IL-15 or IL-15 plus anti-IL-15 monoclonal antibody (MoAb IgG1) during $24 \mathrm{~h}$ and then challenged with $\mathrm{Pb} 18$ in a ratio of 50 monocytes per one fungus for $4 \mathrm{~h}$. The results are expressed as mean \pm standard error of mean from triplicate cultures of monocytes obtained from 26 subjects. Asterisk means p $<0.05$ vs. control (C) and IL-15 + $\operatorname{MoAb}(50,25$ and $12.5 \mathrm{ng} / \mathrm{mL})$.
IL-15 increases the oxidative metabolism of human monocytes - To determine whether the Pb18 killing by IL-15-activated monocytes was dependent on oxidative metabolism, the levels of $\mathrm{O}_{2}{ }^{-}$and $\mathrm{H}_{2} \mathrm{O}_{2}$ were evaluated. Notably, treatment of monocytes with IL-15 led to higher levels of $\mathrm{O}_{2}^{-}$release when compared with monocytes cultured without stimulus. Human monocytes treated with IL-15 at concentrations of 50,25 and $12.5 \mathrm{ng} / \mathrm{mL}$ for $24 \mathrm{~h}$ showed a significant increase in $\mathrm{O}_{2}-$ production for all doses of IL-15 employed when compared to untreated control cultures (Fig. 2). Higher levels of $\mathrm{O}_{2}^{-}$production were also observed in cultures of monocytes challenged with Pb18 in comparison with control cultures. When these infected cells were pretreated with IL-15, a significant increase in $\mathrm{O}_{2}{ }_{2}^{-}$was observed with $50 \mathrm{ng} / \mathrm{mL}$ of IL-15 in comparison with the $\mathrm{Pb} 18$ culture alone.

Monocytes cultured with RPMI medium alone released basal levels of $\mathrm{H}_{2} \mathrm{O}_{2}$, whereas incubation with IL-15, especially at the concentration of $50 \mathrm{ng} / \mathrm{mL}$, induced significantly higher levels of $\mathrm{H}_{2} \mathrm{O}_{2}$. Fig. 3 shows that the $\mathrm{Pb} 18$ challenge had an inhibitory effect on $\mathrm{H}_{2} \mathrm{O}_{2}$ release from monocytes, with levels significantly lower than those observed under other culture conditions. However, activation of these cells with different concentrations of IL-15 for $24 \mathrm{~h}$ followed by challenge with the fungus resulted in higher levels of $\mathrm{H}_{2} \mathrm{O}_{2}$ released by monocytes in comparison to cells without stimulus and with $\mathrm{Pb} 18$. The results therefore indicate that the inhibitory effect of $\mathrm{Pb} 18$ on $\mathrm{H}_{2} \mathrm{O}_{2}$ release was reversed by IL-15, especially at a concentration of $50 \mathrm{ng} / \mathrm{mL}$.

IL-15 modulates cytokine production by monocytes - Supernatants recovered from cells treated with IL-15 $(50 \mathrm{ng} / \mathrm{mL})$ for $24 \mathrm{~h}$ and challenged with $\mathrm{Pb} 18$ for $18 \mathrm{~h}$ were evaluated for TNF- $\alpha$, IL-6, IL-15 and IL-10 production. LPS was employed as the positive control in all

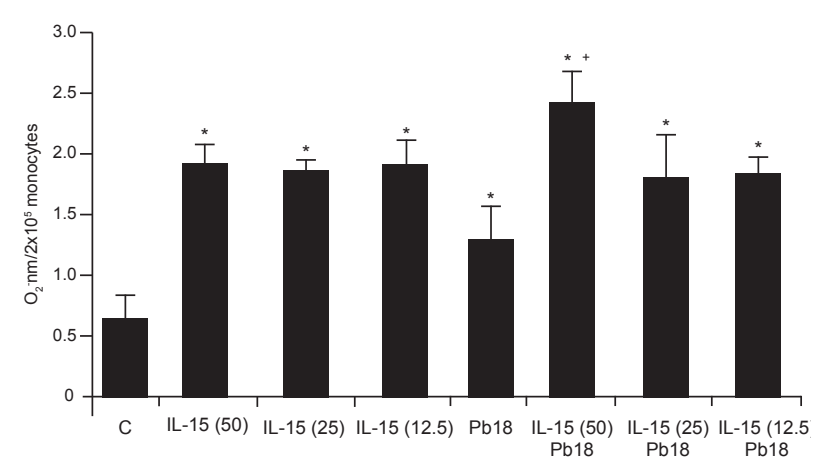

Fig. 2: interleukin (IL)-15 augments superoxide anion $\left(\mathrm{O}_{2}^{-}\right)$production by monocytes challenged with Paracoccidioides brasiliensis (Pb18). Cells were assayed after monocytes treatment with IL-15 $(50,25$ and $12.5 \mathrm{ng} / \mathrm{mL})$ during $24 \mathrm{~h}$ and challenge with $\mathrm{Pb} 18$ in a ratio of 50 monocytes per one fungus. The results are expressed as mean \pm standard error of mean from triplicate cultures of monocytes obtained from 25 subjects. Asterisk means $\mathrm{p}<0.05$ vs. control (C). $+: \mathrm{p}<0.05$ vs. $\mathrm{Pb} 18$. 


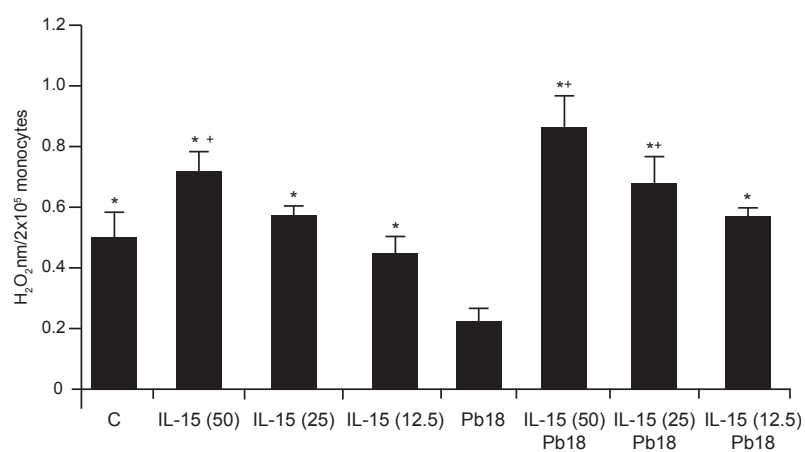

Fig. 3: interleukin (IL)-15 stimulate hydrogen peroxide $\left(\mathrm{H}_{2} \mathrm{O}_{2}\right)$ release by monocytes challenged with Paracoccidioides brasiliensis $(\mathrm{Pb} 18)$. Cells were assayed after monocytes incubation with IL-15 $(50,25$ and $12.5 \mathrm{ng} / \mathrm{mL})$ during $24 \mathrm{~h}$ and challenged with $\mathrm{Pb} 18$ in a ratio of 50 monocytes per one fungus. The results are expressed as mean \pm standard error of mean from triplicate cultures of monocytes obtained from 25 subjects. Asterisk means $\mathrm{p}<0.05$ vs. control (C). $+: \mathrm{p}<0.05$ vs. Pb18.

cultures. As shown in Fig. 4A, TNF- $\alpha$ production by human monocytes was significantly increased after IL-15 activation. High levels of TNF- $\alpha$ were observed after the fungus challenge, showing an enhanced effect of IL-15 on cell stimulation with Pb18. The results show that IL15 is able to increase TNF- $\alpha$ production by uninfected cultures after $24 \mathrm{~h}$ of treatment and by cells challenged in vitro with Pb18.

The production of IL- 6 by human monocytes was significantly higher after activation with IL-15 than in control cultures. A significant increase in IL-6 release was observed when monocytes were challenged with $\mathrm{Pb} 18$ or were pre-activated with IL-15 and challenged with the fungus in comparison with cultures without stimulus. However, treatment with IL-15 did not affect the production of this cytokine when monocytes were challenged with Pb18 (Fig. 4B).

Monocyte cultures treated with IL-15 for $24 \mathrm{~h}$ reflected the autocrine effect of IL-15, as significantly higher levels of IL-15 were observed in these cell cultures without stimulus (Fig. 4C). Pb18 induced higher levels of IL-15 in human monocytes and when these cells were treated with IL-15, the cytokine production was significantly increased.

The levels of IL-10 detected after treatment with IL15 are shown in Fig. 4D. Pb18 induced higher levels of IL-10 when compared with non-stimulated cells. However, IL-10 production in monocytes activated by IL-15 and challenged with $\mathrm{Pb} 18$ was significantly higher than in cultures challenged only with the fungus.

\section{DISCUSSION}

Phagocytic cells play a critical role in host defenses, enhancing their function mainly after cell stimulation with recombinant inflammatory cytokines. Because IL15 has low cytoxicity in vivo (Munger et al. 1995), the ability of this cytokine to modulate human monocyte function against $\mathrm{Pb} 18$ was examined to understand the
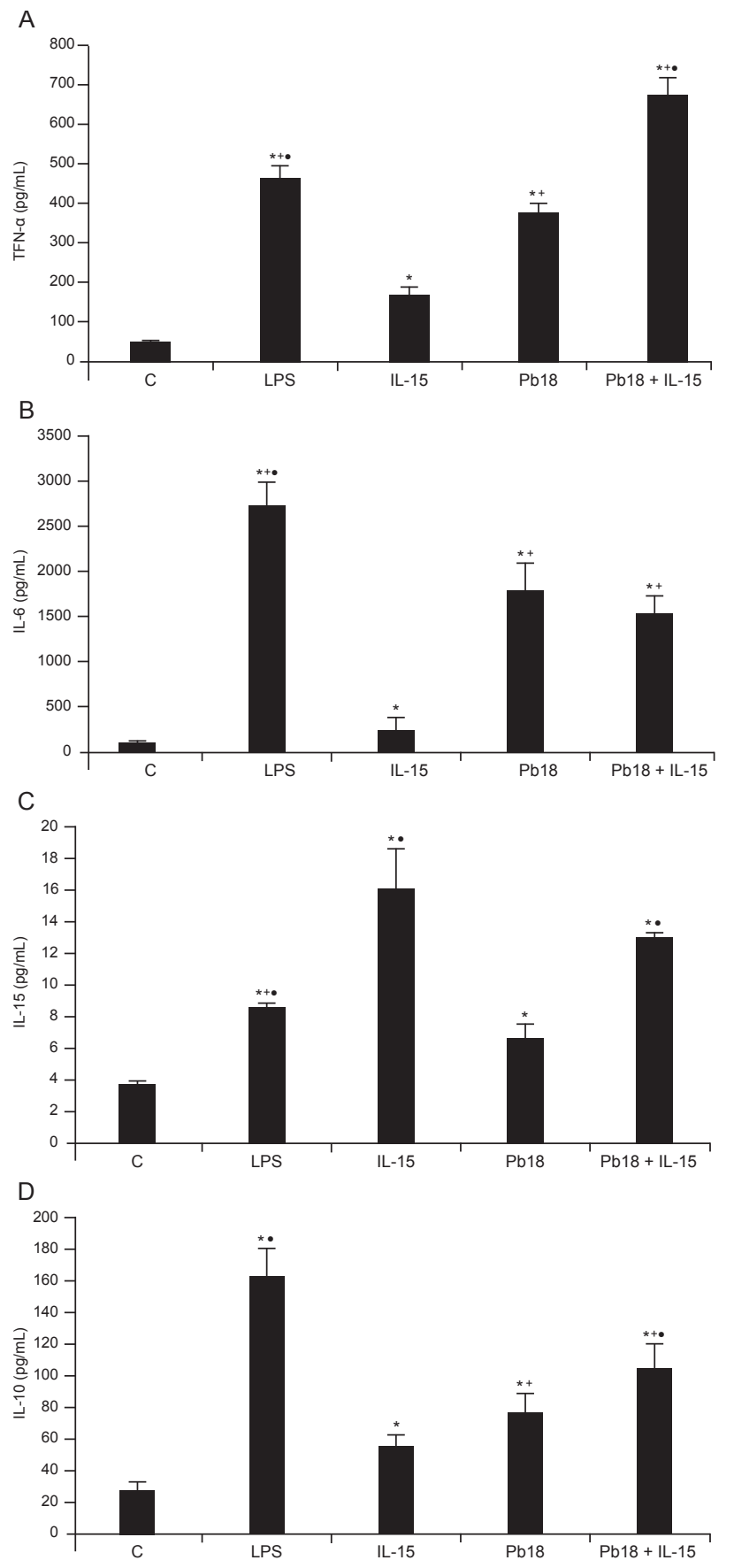

Fig. 4: effect of interleukin (IL)-15 on tumor necrosis factor-alpha (TNF- $\alpha$ ) (A), IL-10 (B) IL-6 (C) and IL-15 (D) production. Monocytes were cultured with IL-15 (50 ng/mL) during $24 \mathrm{~h}$ and challenged with Paracoccidioides brasiliensis ( $\mathrm{Pb18}$ ) in a ratio of 50 monocytes per one fungus during $18 \mathrm{~h}$. The results are expressed as mean \pm standard error of mean and derived from triplicates cultures of monocytes obtained from 25 subjects. Asterisk means $\mathrm{p}<0.05$ vs. control (C). LPS: lypopolisaccharide; + : $\mathrm{p}<0.05$ vs. IL- $15 ; \bullet: \mathrm{p}<0.05$ vs. Pb18.

host defense mechanisms against the fungus. The present study therefore focused on investigating the effect of IL-15 on the induction of Pb18 killing by human monocytes, which is closely associated with the innate immune response. 
The present results indicate that in vitro treatment with IL-15 significantly increases monocyte fungicidal activity against $\mathrm{Pb} 18$, mainly at a concentration of $50 \mathrm{ng} /$ $\mathrm{mL}$, showing that IL-15 potentiates antimicrobial activity in these cells. In addition, the results demonstrated that monocyte treatment with a MoAb anti-IL-15 abrogated this fungicidal activity. Prior studies showed that IL-15 and IL-2 significantly contributed to lymphocyte proliferation and lymphocyte-mediated anticryptococcal activity in both, encapsulated and acapsular $C$. neoformans (Mody et al. 1998). Interestingly, IL-15 restored lymphocyte proliferation and anticryptococcal activity that had been abrogated by blocking IL-2. The mechanism underlying this anticryptococcal activity was described by Ma et al. (2002), who reported that the antifungal activity triggered by IL- 15 over T CD8 cells correlated with the up-regulation of granulysin, located in the acidic granules. Furthermore, antibodies against IL-15 were able to neutralize this effect. IL-15 may also directly induce $\mathrm{Pb} 18$ killing by human neutrophils, a different cellular population also involved in $\mathrm{Pb} 18$ resistance, by an oxidative pathway (Tavian et al. 2008).

The mechanisms involved in Pb18 killing by human monocytes activated with IL-15 were investigated in the present study. IL-15 enhanced the generation of $\mathrm{O}_{2}^{-}$by monocytes challenged or not with $\mathrm{Pb} 18$ in all the concentrations employed. Vázquez et al. (1998) showed that IL-15 stimulates oxidative metabolism, increasing candidacidal activity and $\mathrm{O}_{2}^{-}$production in monocytes, which is in agreement with the present data. Our results suggest a correlation between $\mathrm{O}_{2}^{-}$production and monocyte fungicidal activity against $\mathrm{Pb} 18$, as high levels of $\mathrm{O}_{2}{ }^{-}$were observed in IL-15 activated co-cultures and these cells presented high fungicidal activity in all IL-15 concentrations, showing that this metabolite is involved in human monocyte fungicidal activity.

The yeast form of $\mathrm{Pb} 18$ has been shown to be susceptible to the effects of $\mathrm{H}_{2} \mathrm{O}_{2}$ at $\mu \mathrm{M}$ concentrations in the $\mathrm{H}_{2} \mathrm{O}_{2}$ horseradish peroxidase-halide system (McEwen et al. 1984). The assessment of $\mathrm{H}_{2} \mathrm{O}_{2}$ production revealed that IL15 directly increased $\mathrm{H}_{2} \mathrm{O}_{2}$ production. In the present study when cells were pre-activated with IL-15 and challenged with the fungus, $\mathrm{H}_{2} \mathrm{O}_{2}$ production was lower in all groups, excepted in cells treated with IL-15 at $50 \mathrm{ng} / \mathrm{mL}$. The fungus decreased $\mathrm{H}_{2} \mathrm{O}_{2}$ levels in cultures of non treated monocytes, or cells activated with IL-15 at 25 and $12.5 \mathrm{ng} / \mathrm{mL}$. However, besides directly increasing $\mathrm{H}_{2} \mathrm{O}_{2}$ production by monocytes, IL-15 at the highest dose $(50 \mathrm{ng} / \mathrm{mL})$ restored the $\mathrm{H}_{2} \mathrm{O}_{2}$ production that was inhibited by $\mathrm{Pb} 18$. The inhibition of $\mathrm{H}_{2} \mathrm{O}_{2}$ production caused by the fungus in monocyte cultures can be explained by its ability to produce cytosolic and peroxisomal catalase isoenzymes, showing that high-dose treatments with $\mathrm{H}_{2} \mathrm{O}_{2}$ lead to an early increase in total catalase enzymatic activities, which is indicative of post-transcriptional regulation (Campos et al. 2005, Felipe et al. 2005, Dantas et al. 2008).

Another potential mechanism to explain the IL-15induced enhancement of fungicidal activity could be its ability to stimulate the release of other proinflammatory cytokines that maintain monocyte activation. In the pres- ent study, monocytes challenged with $\mathrm{Pb} 18$ released both pro and anti-inflammatory cytokines and cell activation with IL-15 induced high levels of TNF- $\alpha$, the main cytokine involved in the effective killing of $\mathrm{Pb} 18$ in vitro (Calvi et al. 2003, Carmo et al. 2006). In experimental PCM models, persistent TNF- $\alpha$ production has been associated with resistance to $\mathrm{Pb} 18$ infection, which is also essential for the control of fungal dissemination (Bocca et al. 1998, Souto et al. 2000, Nascimento et al. 2002).

High IL-6 levels were observed only when cells were challenged with the fungus; monocyte activation with IL15 and challenge with Pb18 did not stimulate IL-6 production. This finding is significant because monocytes from PCM patients produce high levels of IL-6 during the active stages of the disease (Peraçoli et al. 2003) and IL-6 deactivates macrophages with the consequent reduction of microbicidal activity (Blanchard et al. 1991, Bermudez et al. 1992). Furthermore, in a previous study we demonstrated that IL-6 increases Pb18 growth in human monocyte cultures, suggesting that this cytokine may contribute to the pathogenesis of $\mathrm{Pb} 18$ infection by promoting fungal growth during interaction with phagocytes. The effect of IL-6 on suppressing fungicidal activity was correlated with the downregulation of TNF- $\alpha$ production by monocytes (Siqueira et al. 2009). Thus, the results of the present study suggest that IL-15 might compensate for the IL-6 induced suppression of monocyte activation caused by $\mathrm{Pb} 18$ by increasing TNF- $\alpha$ production.

Treatment of monocytes with IL-15 $(50 \mathrm{ng} / \mathrm{mL})$ led to an increase of its release even after the challenge with $\mathrm{Pb} 18$. This is an important finding because a minimal endogenous IL-15 production by human monocytes is required for optimal production of IFN- $\gamma$ by NK cells, which are likely to have a significant role during the innate immune response to certain infections (Carson et al. 1994). The present observation that IL-15 may synergize with other inflammatory cytokines to activate the effector cells for protection against microbial infections is in agreement with findings reported by other authors (Yoshikai \& Nishimura 2000).

Higher levels of IL-10 were detected in monocyte cultures challenged with $\mathrm{Pb} 18$ and a more significant increase was detected in cultures of IL-15-activated monocytes. Considering the suppressor effects of IL-10, its production in response to various microorganisms, including fungi, has been regarded as an important host evasion mechanism (Redpath et al. 2001). The same mechanism could explain the activity of $\mathrm{Pb} 18$, as high concentrations of this cytokine were detected in patients' serum (Fornari et al. 2001) and in peripheral blood cell culture supernatants (Benard et al. 2001, Oliveira et al. 2002). Moreover, monocytes from patients (Peraçoli et al. 2003) and monocytes from normal individuals challenged with the fungus (Kurokawa et al. 2007) spontaneously release high concentrations of this cytokine in vitro. In experimental models of PCM infection, susceptibility was associated with high levels of IL-10 (Calich \& Kashino 1998). Thus, IL-10 has important regulatory roles in immunological and inflammatory responses by inhibiting the production of pro-inflammatory cytokines by monocytes (de Waal 
Malefyt et al. 1991). The production of IL-10 observed in the present study may play a role in the control of the Pb18-induced inflammatory immune response and IL-15 could be involved in potentiating this effect.

Our findings suggest that IL-15 may induce Pb18 killing by human monocytes through the activation of oxidative metabolism dependent on TNF- $\alpha$ production. Further studies are required to test monocyte functions and cytokine activation in patients with PCM to enable a better understanding of host-parasite interactions during mycosis.

\section{REFERENCES}

Anjos AR, Calvi SA, Ferracini R, Peraçoli MT, Silva CL, Soares AM 2002. Role of Paracoccidioides brasiliensis cell wall fraction containing beta-glucan in tumor necrosis factor-alpha production by human monocytes: correlation with fungicidal activity. Med Mycol 40: 377-382.

Benard G, Romano CC, Cacere CR, Juvenale M, Mendes-Giannini MJ, Duarte AJ 2001. Imbalance of IL-2, IFN-gamma and IL-10 secretion in the immunosupression associated with human paracoccidioidomycosis. Cytokine 13: 248-252.

Bermudez LE, Wu M, Petrofsky M, Young LS 1992. Interleukin-6 antagonizes tumor necrosis factor-mediated mycobacteriostatic and mycobactericidal activities in macrophages. Infect Immun 60: $4245-4252$.

Blanchard DK, Michelini-Norris MB, Pearson CA, Freitag CS, Djeu JY 1991. Mycobacterium avium-intracellulare induces interleukin-6 from human monocytes and large granular lymphocytes. Blood 77: 2218-2224.

Bocca AL, Hayashi EE, Pinheiro AG, Furlanetto AB, Campanelli AP, Cunha FQ, Figueiredo F 1998. Treatment of Paracoccidioides brasiliensis-infected mice with a nitric oxide inhibitor prevents the failure of cell-mediated immune response. J Immunol 161: 3056-3063.

Bordon AP, Dias-Melicio LA, Acorci MJ, Calvi SA, Serrão Peraçoli MT, Victoriano de Campos Soares AM 2007. Prostaglandin E2 inhibits Paracoccidioides brasiliensis killing by human monocytes. Microbes Infect 9: 744-747.

Brummer E 1994. Interaction of Paracoccidioides brasiliensis with host defense cells. In M Franco, CS Lacaz, AM Restrepo, G Del Negro (eds.), Paracoccidioidomycosis, CRC Press, Florida, p. $213-224$.

Calich VL, Kashino SS 1998. Cytokines produced by susceptible and resistant mice in the course of Paracoccidioides brasiliensis infection. Braz J Med Biol Res 31: 615-623.

Calvi SA, Peraçoli MT, Mendes RP, Marcondes-Machado J, Fecchio D, Marques SA, Soares AM 2003. Effect of cytokines on the in vitro fungicidal activity of monocytes from paracoccidioidomycosis patients. Microbes Infect 5: 107-113.

Campos EG, Jesuino RS, Dantas A da S, Brígido M de M, Felipe MS 2005. Oxidative stress response in Paracoccidioides brasiliensis. Genet Mol Res 4: 409-429.

Carmo JP, Dias-Melicio LA, Calvi SA, Peraçoli MT, Soares AM 2006. TNF-alpha activates human monocytes for Paracoccidioides brasiliensis killing by an $\mathrm{H}_{2} \mathrm{O}_{2}$-dependent mechanism. Med Mycol 44: 363-368.

Carson WE, Giri JG, Lindemann MJ, Linett ML, Ahdieh M, Paxton R, Anderson D, Eisenmann J, Grabstein K, Caligiuri MA 1994. Interleukin (IL) 15 is a novel cytokine that activates human natural killer cells via components of the IL-2 receptor. $J$ Exp Med 180: 1395-1403.
D’Agostino P, Milano S, Arcoleo F, Di Bella G, La Rosa M, Ferlazzo V, Caruso R, Chifari N, Vitale G, Mansueto S, Cillari E 2004. Interleukin-15, as interferon-gamma, induces the killing of Leishmania infantum in phorbol-myristate-acetate-activated macrophages increasing interleukin-12. Scand J Immunol 60: 609-614.

Dantas AS, Andrade RV, de Carvalho MJ, Felipe MS, Campos EG 2008. Oxidative stress response in Paracoccidioides brasiliensis: assessing catalase and cytochrome c peroxidase. Mycol Res 112: 747-756.

de Waal Malefyt R, Abrams J, Bennett B, Figdor CG, de Vries JE 1991. Interleukin-10 (IL-10) inhibits cytokine synthesis by human monocytes: an autoregulatory role of IL-10 produced by monocytes. J Exp Med 174: 1209-1220.

Dooley DP, Cox RA, Hestilow KL, Dolan MJ, Magee DM 1994. Cytokine induction in human coccidioidomycosis. Infect Immun 62: 3980-3983.

Felipe MS, Andrade RV, Arraes FB, Nicola AM, Maranhão AQ, Torres FA, Silva-Pereira I, Poças-Fonseca MJ, Campos EG, Moraes LM, Andrade PA, Tavares AH, Silva SS, Kyaw CM, Souza DP, Pereira M, Jesuíno RS, Andrade EV, Parente JA, Oliveira GS, Barbosa MS, Martins NF, Fachin AL, Cardoso RS, Passos GA, Almeida NF, Walter ME, Soares CM, Carvalho MJ, Brígido MM, PbGenome Network 2005. Transcriptional profiles of the human pathogenic fungus Paracoccidioides brasiliensis in mycelium and yeast cells. J Biol Chem 280: 24706-24714.

Forcina G, D'Ettorre G, Mastroianni CM, Carnevalini M, Scorzolini L, Ceccarelli G, D’Agostino C, Lichtner M, Massetti AP, Vullo V 2004. Interleukin-15 modulates interferon-gamma and betachemokine production in patients with HIV infection: implications for immune-based therapy. Cytokine 25: 283-290.

Fornari MC, Bava AJ, Guereño MT, Berardi VE, Silaf MR, Negroni R, Diez RA 2001. High serum interleukin-10 and tumor necrosis factor alpha levels in chronic paracoccidioidomycosis. Clin Diagn Lab Immunol 8: 1036-1038.

Franco MF 1987. Host-parasite relationships in paracoccidioidomycosis. J Med Vet Mycol 25: 5-18.

Franco MF, Mendes RP, Moscardi-Bacchi M, Rezkallah-Iwasso MT, Montenegro MR 1989. Paracoccidioidomycosis. Bailliere's Clin Trop Med Commun 4: 185-220.

Grabstein KH, Eisenman J, Shanebeck K, Rauch C, Srinivasan S, Fung V, Beers C, Richardson J, Schoenborn MA, Ahdieh M, Johnson L, Alderson MR, Watson JD, Anderson DM, Giri JG 1994. Cloning of a T cell growth factor that interacts with the beta chain of the interleukin-2 receptor. Science 264: 965-968.

Kurokawa CS, Araujo JP Jr, Soares AM, Sugizaki MF, Peraçoli MT 2007. Pro- and anti-inflammatory cytokines produced by human monocytes challenged in vitro with Paracoccidioides brasiliensis. Microbiol Immunol 51: 421-428.

Li CY, Lam KW, Yam LT 1973. Esterases in human leukocytes. J Histochem Cytochem 21: 1-12.

Louie A, Baltch AL, Smith RP, Franke MA, Ritz WJ, Singh JK, Gordon MA 1994. Tumor necrosis factor alpha has a protective role in a murine model of systemic candidiasis. Infect Immun 62: 2761-2772.

Ma LL, Spurrell JC, Wang JF, Neely GG, Epelman S, Krensky AM, Mody CH 2002. CD8 T cell-mediated killing of Cryptococcus neoformans requires granulysin and is dependent on CD4 T cells and IL-15. J Immunol 169: 5787-5795.

McEwen JG, Sugar AM, Brummer E, Restrepo A, Stevens DA 1984. Toxic effect of products of oxidative metabolism on the yeast form of Paracoccidioides brasiliensis. J Med Microbiol 18: 423-428. 
Mody CH, Spurrell JC, Wood CJ 1998. Interleukin-15 induces antimicrobial activity after release by Cryptococcus neoformansstimulated monocytes. J Infect Dis 178: 803-814.

Munger W, DeJoy SQ, Jeyaseelan R Sr, Torley LW, Grabstein KH, Eisenmann J, Paxton R, Cox T, Wick MM, Kerwar SS 1995. Studies evaluating the antitumor activity and toxicity of interleukin-15, a new T cell growth factor: comparison with interleukin-2. Cell Immunol 165: 289-293.

Musso T, Calosso L, Zucca M, Millesimo M, Ravarino D, Giovarelli M, Malavasi F, Ponzi AN, Paus R, Bulfone-Paus S 1999. Human monocytes constitutively express membrane-bound, biologically active, and interferon-gamma-upregulated interleukin-15. Blood 93: 3531-3539.

Nascimento FR, Calich VL, Rodríguez D, Russo M 2002. Dual role for nitric oxide in paracoccidioidomycosis: essential for resistance, but overproduction associated with susceptibility. J Immunol 168: 4593-4600.

Nishimura H, Hiromatsu K, Kobayashi N, Grabstein KH, Paxton R, Sugamura K, Bluestone JA, Yoshikai Y 1996. IL-15 is a novel growth factor for murine gamma delta $\mathrm{T}$ cells induced by $\mathrm{Sal}$ monella infection. J Immunol 156: 663-669.

Oliveira SJ, Mamoni RL, Musatti CC, Papaiordanou PM, Blotta MH 2002. Cytokines and lymphocyte proliferation in juvenile and adult forms of paracoccidioidomycosis: comparison with infected and non-infected controls. Microbes Infect 4: 139-144.

Peraçoli MT, Kurokawa CS, Calvi SA, Mendes RP, Pereira PC, Marques SA, Soares AM 2003. Production of pro- and antiinflammatory cytokines by monocytes from patients with paracoccidioidomycosis. Microbes Infect 5: 413-418.

Redpath S, Ghazal P, Gascoigne NR 2001. Hijacking and exploitation of IL-10 by intracellular pathogens. Trends Microbiol 9: 86-92.

Russo M, Teixeira HC, Marcondes MC, Barbuto JA 1989. Superoxideindependent hydrogen peroxide release by activated macrophages. Braz J Med Biol Res 22: 1271-1273.

Singer-Vermes LM, Ciavaglia MC, Kashino SS, Burger E, Calich VL 1992. The source of the growth-promoting factor(s) affects the plating efficiency of Paracoccidioides brasiliensis. J Med Vet Mycol 30: 261-264.
Siqueira KZ, Campos Soares AM, Dias-Melicio LA, Calvi SA, Peraçoli MT 2009. Interleukin-6 treatment enhances human monocyte permissiveness for Paracoccidioides brasiliensis growth by modulating cytokine production. Med Mycol 47: 259-267.

Smith JG, Magee DM, Williams DM, Graybill JR 1990. Tumor necrosis factor-alpha plays a role in host defense against Histoplasma capsulatum. J Infect Dis 162: 1349-1353.

Soares AM, Calvi SA, Peraçoli MT, Fernandez AC, Dias LA, Dos Anjos AR 2001. Modulatory effect of prostaglandins on human monocyte activation for killing of high- and low-virulence strains of Paracoccidioides brasiliensis. Immunology 102: $480-485$.

Souto JT, Figueiredo F, Furlanetto A, Pfeffer K, Rossi MA, Silva JS 2000. Interferon-gamma and tumor necrosis factor-alpha determine resistance to Paracoccidioides brasiliensis infection in mice. Am J Pathol 156: 1811-1820.

Tavian EG, Dias-Melicio LA, Acorci MJ, Graciani AP, Peraçoli MT, Soares AM 2008. Interleukin-15 increases Paracoccidioides brasiliensis killing by human neutrophils. Cytokine 41: 48-53.

Van Belle T, Grooten J 2005. IL-15 and IL-15 Ralpha in CD4+ T cell immunity. Arch Immunol Ther Exp (Warsz) 53: 115-126.

Vázquez N, Walsh TJ, Friedman D, Chanock SJ, Lyman CA 1998. Interleukin-15 augments superoxide production and microbicidal activity of human monocytes against Candida albicans. Infect Immun 66: 145-150.

Vecchiarelli A, Retini C, Pietrella D, Monari C, Tascini C, Beccari T, Kozel TR 1995. Downregulation by cryptococcal polysaccharide of tumor necrosis factor alpha and interleukin-1 beta secretion from human monocytes. Infect Immun 63: 2919-2923.

Winn RM, Gil-Lamaignere C, Roilides E, Simitsopoulou M, Lyman CA, Maloukou A, Walsh TJ 2003. Selective effects of interleukin (IL)-15 on antifungal activity and IL-8 release by polymorphonuclear leukocytes in response to hyphae of Aspergillus species. J Infect Dis 188: 585-590.

Yoshikai Y, Nishimura H 2000. The role of interleukin 15 in mounting an immune response against microbial infections. Microbes Infect 2: 381-389. 